\title{
RELATIONSHIPS BETWEEN THE SOURCE OF HEALTH INFORMATION AND THE BEHAVIOR OF MOTHERS OF CHILDREN UNDER 5 YEARS OLD: CROSS-SECTIONAL STUDY ANALYSIS
}

DOI: 10.36740/WLek202103212

\author{
Kostyantyn V. Balashov ${ }^{1,2}$, Gennady 0. Slabkiy ${ }^{2}$, Olesya P. Hulchiy ${ }^{1}$, Nadiia M. Zakharova' ${ }^{1}$, Solomiya M. Turianytsia' ${ }^{1}$ \\ 'SHUPYK NATIONAL HEALTHCARE UNIVERSITY OF UKRAINE, KYIV, UKRAINE \\ ${ }^{2}$ UZHHOROD NATIONAL UNIVERSITY, UZHHOROD, UKRAINE
}

\begin{abstract}
The aim: Is to investigate relationships between trusted sources of health information and people's behavior, including their attitudes toward vaccination and their willingness to seek medical care.

Materials and methods: The responses of 4,354 mothers of children under 5 years of age from all regions of Ukraine, who participated in the Multi-Indicator Cluster Household Survey (MICS-2012) were analyzed. The respondents were divided into separate groups using two-step cluster analysis.

Results: 6 clusters of respondents were identified, depending on the trusted source of health information identified by them, including those who trust only physicians ( $50.0 \%)$, friends (15.3\%), all information channels (15.2\%) or do not trust anyone (6.0\%). The most important statistically significant differences in the level of vaccination coverage and willingness to seek medical care were found for a group of people who do not trust any source of information about health or trust only information from the Internet. People who trust information from physicians or pharmacy workers were the most active in vaccinating and seeking medical care.

Conclusions: Communication with patients who do not trust anyone through social networks seems to be a promising way to raise awareness of this group of people about health and increase the level of trust in physicians or certain medical services.
\end{abstract}

KEY WORDS: Information Seeking Behavior, Communication Barriers, Vaccination, cluster analysis

Wiad Lek. 2021;74(3 p.ll):630-635

\section{INTRODUCTION}

WHO names credibility as one of the six most important principles for effective communications in health [1]. Physician's role in the implementation of communication on health is indispensable, which is confirmed by data from Ukrainian and foreign studies: health care workers are not only the most common and authoritative source of health information [2-3] but also play an important role as experts in disseminating health information via other channels of communication, incl. the Internet [4]. At the same time, usage of the Internet as an additional source of information for the patient can have a positive effect on further communication with the physician [5].

Previous studies have identified the relationships between considering different channels of health information as trustworthy and demographic or social characteristics [6] or determinants of NCD development [7].

At the same time, high incidence rates of non-communicable diseases, a lot of mistrust of vaccination, etc. indicate that considering physicians as a source of reliable information does not always lead to a practical result - taking actions at maintaining health.

To gain a more holistic view of the factors and manifestations of a physician's credibility, the data of the Multi-Indicator Cluster Survey of Households (MICS-2012) [8] were analyzed to investigate relationships between trusted sources of health information and people's behavior, including their attitudes toward vaccination and their willingness to seek medical care.

\section{THE AIM}

The aim is to investigate relationships between trusted sources of health information and people's behavior, including their attitudes toward vaccination and their willingness to seek medical care.

\section{MATERIALS AND METHODS}

In 2012 Multi-Indicator Cluster Household Survey (MICS2012) was conducted with the assistance of UNICEF, the Swiss Cooperation Office, and the United States Agency for International Development. In this article responses of 4,354 mothers of children under 5 years of age from all regions of Ukraine, who participated in the MICS-2012 were analyzed.

Rates of usage of health information sources, willingness to seek medical care under threatening life or health condition of a child, attitudes to vaccination, vaccination records obtained from children's vaccination cards were analyzed. 
Table I. Clusters of Respondents by Trusted Information Sources about Health

\begin{tabular}{|c|c|c|c|}
\hline №, Name & $\begin{array}{l}\text { Number } \\
\text { of people }\end{array}$ & Fraction (\%) & Trusted Sources (Support Rate in the Cluster, \%) \\
\hline $\begin{array}{l}\text { I, do not trust } \\
\text { anyone }\end{array}$ & 262 & 6 & Noone (49.6), the Internet (27.9) ${ }^{1}$ \\
\hline II, trust everyone & 661 & 15.2 & $\begin{array}{l}\text { Health care professionals }(75,2) \text {, TV }(49,5) \text {, books }(26,6) \text {, pharmacies }(26,3) \text {, } \\
\text { friends }(24,2) \text {, the Internet }(19,4) \text {, journals }(16,0) \text {, magazines }(9,8) \text {, the Internet } \\
(8,0) \text {, the radio }(6,5) \text {, other }(3.2)\end{array}$ \\
\hline III, trust friends & 666 & 15.3 & Friends $(100)$, health care professionals $(80,3)$, the Internet $(11,1)$, \\
\hline IV, trust the Internet & 191 & 4.4 & The Internet (100), health care professionals (100) \\
\hline V, trust pharmacies & 396 & 9.1 & Pharmacies (100), health care professionals $(100)$, friends $(23,2)$ \\
\hline VI, trust physicians & 2178 & 50.0 & Health care professionals (100) \\
\hline Total & & 100 & \\
\hline
\end{tabular}

${ }^{1}$ This cluster also includes individuals who for any reason did not answer questions about trusting health information sources.

Table II. Demographic and Social Characteristics of Clusters

\begin{tabular}{|c|c|c|c|c|c|}
\hline Cluster & $\begin{array}{c}\text { Age } \\
\text { (Ratio 20-24 / 35-39) }\end{array}$ & $\begin{array}{c}\text { Higher Education } \\
\text { Rate,\% }\end{array}$ & $\begin{array}{c}\text { Urban Population, \% } \\
\text { Region }\end{array}$ & $\begin{array}{l}\text { Computer } \\
\text { Usage, \% }\end{array}$ & $\begin{array}{l}\text { Number of } \\
\text { children }\end{array}$ \\
\hline I, do not trust anyone & $\left(21.7 / 4.9^{11, v, v I}\right)$ & $46.0^{1 \mathrm{~V}}$ & $\begin{array}{l}75.2^{\| 1,111, \mathrm{~V} 1} \\
\text { North }\end{array}$ & $86.7^{\mathrm{IV}}$ & 1.8 \\
\hline II, trust everyone & $(18.9 / \mathbf{1 4 . 5})^{\prime \prime I I}$ & $42.2^{\mid v, v 1}$ & $\begin{array}{l}\mathbf{5 9 . 8}^{1,1 \mathrm{~V}} \\
\text { Center }\end{array}$ & $84.0^{\mathrm{IV}}$ & 1.8 \\
\hline III, trust friends & $\left(23.6^{v} / 11.6\right)^{\| \prime}$ & $38.9^{1 \mathrm{~V}}$ & $\begin{array}{c}64.9^{1,1 \mathrm{~V}} \\
\text { East, West }\end{array}$ & $86.8^{I V}$ & $1.6^{\mathrm{V}, \mathrm{VI}}$ \\
\hline IV, trust the Internet & $(18.3 / 12.0)$ & $58.1^{1,\|,\| I, V, V I}$ & $\begin{array}{l}79.1^{11, I I I, V, V I} \\
\text { North }\end{array}$ & $99.5^{1,\|,\| I,, V, V \mid}$ & $1.6^{\mathrm{V}, \mathrm{VI}}$ \\
\hline V, trust pharmacies & 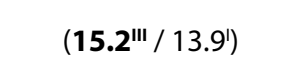 & $33.1^{\mathrm{IV}}$ & $\begin{array}{c}65.4^{1 \mathrm{~V}} \\
\text { East }\end{array}$ & $80.1^{\mathrm{IV}}$ & $1.9^{11, \mathrm{IV}}$ \\
\hline VI, trust physicians & $\left(18.9 / 13.1^{\prime}\right)$ & $36.4^{\mathrm{IV}}$ & $\begin{array}{l}60.5^{1,1 \mathrm{~V}} \\
\text { South }\end{array}$ & $83.3^{1 \mathrm{~V}}$ & $1.89^{111, \mathrm{IV}}$ \\
\hline Total & $19.4 / 12.7$ & 38.7 & 63.2 & 84.5 & 1.8 \\
\hline
\end{tabular}

I, II, III, IV, V, VI - indicate the number of the cluster (within one characteristic) from which statistically significant difference was shown $(\mathrm{p}<0,05)$

To identify typical patterns in the credibility of information sources, the respondents were divided into separate groups using cluster analysis. With the help of the TwoStep cluster analysis algorithm, six clusters were formed, containing from 191 (4.4\%) to 2,178 (50.0\%) individuals. The Silhouette index is 0.7 , the share of accordance of subgroups during the verification by the k-means method was $87 \%$, which indicates the sufficient adequacy of the proposed cluster solution.

For each cluster, the rates of receiving health information from different information sources, the willingness to seek medical care under threatening life or health condition of a child, vaccination coverage (following to the vaccination calendar) and attitudes to vaccination, as well as demographic characteristics were calculated. The probability of the obtained differences was assessed using Bonferroni's method for pairwise comparisons with correction for relative values and one-way analysis of variance (ANOVA) for means. Statistical processing was performed using the SPSS v. 23 package.

\section{RESULTS}

As a result of the analysis, six clusters were created, the core of each was formed by people who trust the certain information source. Representatives of most clusters trust physicians. For respondents in Cluster VI it is the only credible source of information, the representatives of other clusters combine it with one or more other sources.

The presence of relatively large groups of people who have the same set of trusted information sources about health has become the basis for clustering. Depending on the most distinct characteristics, clusters were given short names (Table I).

Statistically significant differences in the demographic parameters of the clusters were found: cluster IV mostly represented by more educated and computerized citizens with the smallest number of children. The second cluster includes older people who live more often in rural areas in the Center of Ukraine (Table II).

At least one-third of the representatives of each cluster receive health information from television. In cluster $\mathrm{V}$ 
Table III. Rates of Obtaining Information about Health from Different Sources (by Clusters)

\begin{tabular}{|c|c|c|c|c|c|c|c|c|c|c|}
\hline \multirow[b]{2}{*}{ Cluster } & \multicolumn{10}{|c|}{ Rates, \% } \\
\hline & Television & Newspapers & Friends & Journals & Radio & $\begin{array}{l}\text { Health Care } \\
\text { Professionals }\end{array}$ & Internet & Pharmacies & Books & Others \\
\hline $\begin{array}{l}\text { I, do not trust } \\
\text { anyone }\end{array}$ & $38.5^{11, \mathrm{~V}}$ & $7.6^{11, \mathrm{~V}}$ & $24.0^{11,11, \mathrm{~V}}$ & $5.3^{11, \mathrm{~V}}$ & $2.7^{\prime \prime}$ & 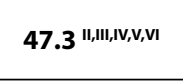 & $42.4^{\mathrm{IV}, \mathrm{V}, \mathrm{VI}}$ & $18.3^{11, \mathrm{~V}}$ & $7.3^{11}$ & 1.5 \\
\hline II, trust all & 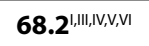 & $23.8^{1, I I, I, V, V, V I}$ & $38.1^{1,111,1, \mathrm{v}, \mathrm{VI}}$ & $24.7^{1, \| 1, I, N, V, V I}$ & $11.5^{1,\|,\|, v, V \mid}$ & $83.7^{\mathrm{I}, \mathrm{N}, \mathrm{V}, \mathrm{VI}}$ & $38.4^{\mathrm{IV}, \mathrm{V}, \mathrm{VI}}$ & $34.3^{1, \| I, I, V, V, V I}$ & $30.0^{1, \|, N, N, Y, V I}$ & 2.0 \\
\hline III, trust friends & $33.6^{11, \mathrm{~V}}$ & $9.0^{11, \mathrm{~V}}$ & 96. $7^{1, \|, 1, V, V, V I}$ & $10.5^{\prime \prime}$ & $3.2^{11}$ & $88.7^{I, V I}$ & $33.0 \mathrm{vv}, \mathrm{vI}$ & $17.3^{\| 1, V}$ & $5.1^{\prime \prime}$ & 0 \\
\hline $\begin{array}{l}\text { IV, trust the } \\
\text { Internet }\end{array}$ & $30.9^{11, \mathrm{~V}}$ & $8.9^{\prime \prime}$ & $19.9^{11,11, \mathrm{v}}$ & $13.1^{\prime \prime}$ & $3.7^{\prime \prime}$ & $95.3^{1,11}$ & $95.3^{1,\|,\|,,,, V)}$ & $12.0^{11, \mathrm{~V}}$ & $7.3^{\prime \prime}$ & 0 \\
\hline $\begin{array}{c}\text { V, trust } \\
\text { pharmacies }\end{array}$ & 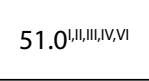 & $16.2^{\mid, 1,1,1, \mathrm{VI}}$ & $46.7^{1,11,1, v, v 1}$ & $14.6^{1, \mathrm{~N}, \mathrm{~V}}$ & $6.8^{\mathrm{vI}}$ & $93.9 \mathrm{l}, \mathrm{ll}, \mathrm{VI}$ & $28.5^{1,1,1, \mathrm{~V}}$ & $85.9^{|, \|, 1,1,1,1, V|}$ & $5.8^{\prime \prime}$ & 0 \\
\hline $\begin{array}{l}\mathrm{Vl} \text {, trust } \\
\text { physicians }\end{array}$ & 35.9 $9^{\|, v}$ & $9.0^{11, \mathrm{~V}}$ & $26.9^{11,111, \mathrm{~V}}$ & $8.4^{\|, \mathrm{v}}$ & $\mathbf{2 . 3 ^ { 1 1 , V }}$ & $97.8^{1,1,1,111, V}$ & $24.6^{1,\|,\|, 1,1 \mathrm{~V}}$ & $18.1^{\Perp, \mathrm{V}}$ & $6.7^{\prime \prime}$ & 0.1 \\
\hline
\end{tabular}

$\mathrm{I}, \mathrm{II}, \mathrm{III}, \mathrm{IV}, \mathrm{V}, \mathrm{VI}$ - indicate the number of the cluster (within one characteristic) from which statistically significant difference was shown $(p<0,05)$

Table IV. Rates of the Willingness to Seek Medical Care Under Threatening Life or Health Condition of a Child

\begin{tabular}{|c|c|c|c|c|c|c|c|c|}
\hline \multirow[b]{2}{*}{ Cluster } & \multirow[b]{2}{*}{$\begin{array}{l}\text { The child } \\
\text { cannot } \\
\text { drink or } \\
\text { breastfeed }\end{array}$} & \multirow[b]{2}{*}{$\begin{array}{l}\text { The child } \\
\text { getting } \\
\text { sicker }\end{array}$} & \multicolumn{6}{|c|}{ Rate, \% } \\
\hline & & & Fever & $\begin{array}{c}\text { Frequent } \\
\text { breathing }\end{array}$ & $\begin{array}{l}\text { Difficulty } \\
\text { breathing }\end{array}$ & $\begin{array}{l}\text { Blood in } \\
\text { the stool }\end{array}$ & $\begin{array}{l}\text { Disturbances } \\
\text { in fluid intake }\end{array}$ & Others \\
\hline I, do not trust anyone & $16.4 \mathrm{IIIV}$ & 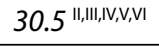 & $68.3 \mathrm{Il}, \mathrm{Il}, \mathrm{V}, \mathrm{V}, \mathrm{VI}$ & $21.0^{\| 1, I I, V, V I}$ & $34.011, I I I, I V, V, V I$ & $23.7^{11, \| I, V, V I}$ & $8.8^{\mathrm{II}, \mathrm{Vl}}$ & $29.8^{\Perp \prime}, \mathrm{V}, \mathrm{VI}$ \\
\hline II, trust all & 23.9 & $53.6^{\prime}$ & $84.6^{1}$ & $34.9^{\mathrm{I}, \mathrm{V}}$ & $60.1^{\prime}$ & $49.0 \mathrm{l}, \mathrm{N}, \mathrm{V}$ & 15.9 & $24.4^{\mathrm{I}, \mathrm{II}, \mathrm{V}}$ \\
\hline III, trust friends & $29.3^{I, V I}$ & $52.1^{\prime}$ & 87.8' & $40.5 \mathrm{I}, \mathrm{VI}$ & $64.1^{\mathrm{l}, \mathrm{VI}}$ & $48.8^{\mathrm{I}, \mathrm{IV}, \mathrm{V}}$ & $19.2^{\prime}$ & $29.4{ }^{\|, V, V I}$ \\
\hline IV, trust the Internet & 27.2 & $49.7^{\prime}$ & 92.7' & $32.5^{v}$ & $61.8^{\prime}$ & $36.1^{11,11, \mathrm{~V}}$ & 15.7 & $26.2^{v}$ \\
\hline$V$, trust pharmacies & $31.8^{I, V I}$ & $60.4^{\mathrm{I}, \mathrm{VI}}$ & $85.9^{1}$ & $47.2^{1, \|, I, I, V I}$ & $65.9 \mathrm{l}, \mathrm{VI}$ & $58.3^{1, I, I I, I, V, V I}$ & 16.7 & $\begin{array}{c}18.2 \\
1, \mathrm{l}, \mathrm{I}, \mathrm{I}, \mathrm{I}, \mathrm{V}, \mathrm{VI}\end{array}$ \\
\hline VI, trust physicians & $21.3^{\mathrm{II}, \mathrm{V}}$ & $48.2^{\mathrm{I}, \mathrm{V}}$ & $86.9^{1}$ & $34.1^{\mathrm{I}, \mathrm{III}, \mathrm{V}}$ & $54.0^{\mathrm{I}, \mathrm{II}, \mathrm{V}}$ & $46.8^{\mathrm{I}, \mathrm{V}}$ & $16.3^{\prime}$ & $25.9^{1, I I, V}$ \\
\hline
\end{tabular}

I, II, III, IV, V, VI - indicate the number of the cluster (within one characteristic) from which statistically significant difference was shown ( $p<0,05)$

$16.2 \%$ of respondents receive health information from newspapers, and $46.7 \%$ from friends and relatives, etc. This information can be used to increase the effectiveness of information campaigns through the combined impact of messages from different sources.

The answers about the willingness to seek medical care under threatening life or health condition of a child and the information on carrying out preventive vaccinations according to the vaccination calendar were analyzed to assess the relationship between considering physicians as a trusted source of information about health and the real activities of respondents.

Respondents assessed the likelihood of seeking medical care in case of fever, difficulty or acceleration of the breathing, the presence of blood in the stool, if a child was getting sicker or has disturbances in fluid intake.

There is a strong correlation between the rates of seeking medical care among respondents from the different clusters (Table IV) ( $\mathrm{r}=0.78$ between cluster I and cluster $\mathrm{V}$ and $\mathrm{r}>0.89$ for other combinations of clusters). This shows the similarity of the hierarchy of threats to children's health among those who prefer different channels of information. This fact, however, reflects parents' perception of the likelihood of facing the problem (fever, if a child was getting sicker - among leaders) than the level of threat it poses (blood in the stool, disturbances in fluid intake - among outsiders).

Statistically significant differences in the rates of the willingness to seek medical care (Table IV) indicate peculiarities of clusters' members: people of cluster $\mathrm{V}$ most often seek medical attention for most reasons (vigilant), except for the item "Other». Instead, the representatives of the first cluster demonstrate opposed beliefs: a relatively high level of requests for medical care due to «other» reasons and the lowest among the clusters - due to the symptoms indicated in the questionnaire.

Respondents of Cluster III seek medical care relatively intensively for both major and other reasons, and of Cluster IV - selectively: quite intensively due to fever or difficulty breathing, but significantly less than other clusters due to blood in the stool or frequent breathing.

Thus, three groups of clusters could be distinguished: cluster I showing negative attitude to health care, cluster $\mathrm{V}$ showing positive attitude (its members seek medical care even more often than Cluster VI, whose members choose physicians as the only trusted source of information) and a group of clusters showing moderately positive mood, the most skeptical of which is the third cluster (those who chose friends and relatives as the trusted source of information). 
Table V. The Coverage by the Vaccination, $\%$

\begin{tabular}{|c|c|c|c|c|c|c|}
\hline \multirow{2}{*}{ Cluster } & \multicolumn{6}{|c|}{ Rate, \% } \\
\hline & BCG & DTaP & Polio & HepB & Hib & MMRV' \\
\hline I, do not trust anyone & $78.2^{11, \mathrm{II}, \mathrm{V}, \mathrm{VI}}$ & $65.3^{\|,\| I I, V, V I}$ & $63.0 \mathrm{IIIII,V,VI}$ & $55.0^{\Perp, V, V I}$ & $58.8^{\mathrm{Il}, \mathrm{II}, \mathrm{V}, \mathrm{VI}}$ & $46.6^{\| \prime, V, V I}$ \\
\hline II, trust all & $89.4^{1}$ & $78.5^{1}$ & $77.5^{1}$ & $71.1^{1,1111}$ & $69.9^{1}$ & $59.0^{1}$ \\
\hline III, trust friends & $88.4^{1}$ & $76.3^{1}$ & $76.0^{1}$ & $62.9^{\Perp, V, V I}$ & $69.8^{1}$ & 55.1 \\
\hline IV, trust the Internet & 88.0 & 73.3 & 73.3 & 66.5 & 67.0 & 53.4 \\
\hline V, trust pharmacies & $90.4^{1}$ & $81.8^{\prime}$ & $81.8^{\prime}$ & $75.3^{1,1111}$ & $75.8^{1}$ & $62.4^{1}$ \\
\hline VI, trust physicians & $90.1^{1}$ & $78.8^{1}$ & $78.2^{1}$ & $70.2^{1,1111}$ & $72.9^{\prime}$ & $59.6^{\prime}$ \\
\hline
\end{tabular}

$\mathrm{I}, \mathrm{II}, \mathrm{III}, \mathrm{IV}, \mathrm{V}, \mathrm{VI}$ - indicate the number of the cluster (within one characteristic) from which statistically significant difference was shown $(\mathrm{p}<0,05)$

BCG - Bacillus Calmette-Guérin vaccine; DTaP - Diphtheria, tetanus, \& pertussis; Polio - Inactivated poliovirus, HepB - Hepatitis B; Hib - Haemophilus influenzae type b; MMRV - Measles, mumps, rubella

1 Significantly less coverage of all clusters by MMRV vaccination is due to the presence of children under 1 year. The share of children under 1 year in the clusters is from 16.8 to $18.7 \%$, the difference is not statistically significant.

Table VI. Attitude to Certain Vaccination Factors

\begin{tabular}{|c|c|c|c|c|c|c|}
\hline \multirow[b]{2}{*}{ Cluster } & \multicolumn{5}{|c|}{ Rate, \% } & \multirow[b]{2}{*}{$\begin{array}{l}\text { Adverse } \\
\text { reactions }\end{array}$} \\
\hline & Effectiveness & Safety & $\begin{array}{l}\text { Readiness to } \\
\text { follow Vaccination } \\
\text { Calendar }\end{array}$ & $\begin{array}{l}\text { Refusal to } \\
\text { Vaccinate }\end{array}$ & $\begin{array}{l}\text { of them, } \\
\text { permanent } \\
\text { refusal }\end{array}$ & \\
\hline I, do not trust anyone & $70.1^{11,11, \mathrm{VI}}$ & 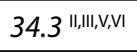 & $68.1^{11,11,, v, \mathrm{VI}}$ & 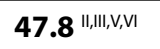 & $35.0 " 1$ & $18.3^{\prime \prime \prime}$ \\
\hline II, trust all & $79.8^{1}$ & $48.8^{1}$ & $79.5^{1}$ & $34.2^{\prime}$ & $15.0^{\prime}$ & $19.1^{111}$ \\
\hline $\mathrm{II}$, trust friends & $81.5^{\prime}$ & $55.1^{1,1 \mathrm{~V}}$ & $82.4^{\prime}$ & $32.4^{1}$ & 25.5 & $29.3^{1, I, V, V I I}$ \\
\hline IV, trust the Internet & 79.6 & $41.4^{\prime \prime \prime}$ & 80.1 & 38.2 & 25.4 & 21.5 \\
\hline $\mathrm{V}$, trust pharmacies & 78.7 & $51.9^{\prime}$ & $81.3^{\prime}$ & $33.4^{\prime}$ & 18.9 & $19.2^{111}$ \\
\hline VI, trust physicians & $81.8^{\prime}$ & $48.6^{\prime}$ & $81.8^{\prime}$ & $32.5^{\prime}$ & 23.1 & $20.8^{\prime \prime \prime}$ \\
\hline
\end{tabular}

$\mathrm{I}, \mathrm{II}, \mathrm{III}, \mathrm{IV}, \mathrm{V}, \mathrm{VI}$ - indicate the number of the cluster (within one characteristic) from which statistically significant difference was shown $(p<0,05)$

Analysis of the coverage of children with preventive vaccinations showed (Table V) that clusters II, III, V, VI mostly do not have statistically significant differences in the vaccination rates. The exception is hepatitis $B$ vaccination, where clusters II, V, and VI form a group of highly vaccinated, and I and III - low-vaccinated. Those who trust the Internet (cluster IV) do not show any statistically significant differences from any other cluster and are moderately vaccinated, and cluster I, accordingly, demonstrates significantly lower levels of vaccination than other clusters (except for cluster IV).

The analysis of respondents' assessment of the effectiveness and safety of vaccination (Table VI), readiness to follow the vaccination calendar confirmed the trends. Respondents from cluster I expressed low support for all three criteria, respondents from III, V, and VI - high, and IV - average support. When asked whether the respondents had the experience of refusing vaccination, $47.8 \%$ of the first cluster and $32.4 \%$ $38.2 \%$ of the remaining clusters answered affirmatively. At the same time, respondents in cluster III reported a significantly higher incidence of adverse reactions in their children $(29,3)$.

\section{DISCUSSION}

The analysis shows that half of the mothers of young children consider physicians to be the only reliable source of health information (cluster VI). In terms of social and demographic characteristics, the group of respondents who trust information from the Internet and physicians (4.4\% of the population) is the most different from other groups: they mostly have a higher education, are residents of cities, and have a lower average number of children.

Respondents from clusters III (trust friends), IV (trust the Internet) and VI (trust physicians) mostly receive information from the source they trust, and clusters I (trust no one), II (trust everyone), and V (trust pharmacies) receive information about health from a wider range of channels. For example, people who trust pharmacies also receive health information from television $(51 \%)$ and friends $(46.7 \%)$

COVID-19 may change the information need of people, for example, a study [9] shows in $202092.6 \%$ of Italians trust scientists, $89,6 \%$ - official websites, and only $4.3 \%$ social media. Health care professionals are remaining as a trusted source of health information because people seek practical information, which is appropriate and validated in their communities [10]. Even one health intervention could cause a prolonged protective effect [11].

Representatives of the first cluster (do not trust anyone) show statistically significantly lower levels of seeking medical care, vaccination coverage, expressed the least support for the points about the safety and effectiveness of vaccination. Almost half of them had the experience of rejecting the 
vaccination. Since this cluster represents approx. $6 \%$ of the population and also includes people, for whom the only trusted source of health information is the Internet, it is important to inform them about health through the information channels they do use (even if people declare do not to trust them), for example, physicians, the Internet, television.

Communicating with people of this cluster also important is to promote and facilitate regular direct communication between respondents and their family physicians. One of the possible options for such interventions is the participation of physicians or public health professionals in a social networks activity, which involves the preparation of posts relevant to the population health issues, participation in discussions in patients groups so on.

Sometimes, mothers do not seek medical care because of the cultural aspects or as they are unaware of the importance of it [12]. For this group, health-related aspects could be effectively embedded to appropriate activities, i.e. language school programs [13]. Healthcare professionals should be trained in cultural sensitivity and have skills in communications to improve seeking medical care and vaccination rates $[12,14]$.

Representatives of the $\mathrm{V}$ cluster (trust pharmacies) demonstrated the highest levels of seeking medical care, coverage, and safety assessments of vaccination. Representatives of the VI cluster (trust physicians) are leaders in vaccination coverage, highly appreciate its effectiveness, safety, and readiness to follow the vaccination calendar, at the same time, less often than representatives of the $\mathrm{V}$ cluster seek medical care.

Representatives of cluster III (trust friends) are ready to follow the vaccination calendar, consider vaccination effective and safe, while most often (29.3\%) stated that they observed side effects from vaccination, and have lower than clusters II, V, and VI coverage by hepatitis B vaccination (62.9\% vs $70.2-75.3 \%)$.

As shown in $[15,16]$ the Internet plays a double role in health communication. The sharing of medical advice in social media by physicians is a trusted and effective method, but also the Internet may reinforce false information and myths.

\section{CONCLUSIONS}

Based on the analysis of the data of the Multi-Indicator Cluster Survey of Households, 6 clusters of respondents were identified, depending on the trusted source of health information identified by them, including those who trust only physicians $(50.0 \%)$, friends (15.3\%), all information channels (15.2\%) or do not trust anyone (6.0\%).

It has been determined that people who do not trust any of the information channels (or trust only information from the Internet) seek significantly less medical care, have lower rates of vaccination coverage, and consider vaccination less effective and safe, compared to other clusters. People who trust information from physicians or pharmacy workers were the most active in vaccinating and seeking medical care.
Communication with patients who do not trust anyone through social networks seems to be a promising way to raise awareness of this group of people about health and increase the level of trust in physicians or certain medical services.

\section{REFERENCES}

1. WHO strategic communications framework for effective communications. World Health Organization. 2017. https://www.who.int/mediacentre/ communication-framework.pdf.

2. Znamenska M.A. Medyko-sotsialne obgruntuvannia systemy komunikatsii v okhoroni zdorovia. Dysertatsiia na zdobuttia naukovoho stupenia doktora medychnykh nauk. Kyiv: NMAP0 imeni P.L. Shupyka. 2015. (In Ukrainian).

3. Nejašmić D., Miošić I.,Vrdoljak D. et al. Awareness and use of evidencebased medicine information among patients in Croatia: a nation-wide cross-sectional study. Croat Med J. 2017;58(4):300-301.

4. Tonsaker T., Bartlett G., Trpkov C. Health information on the Internet. Gold mine or minefield? Can Fam Physician. 2014;60(5):407-408.

5. Eysenbach G. Internet Health Information Seeking and the PatientPhysician Relationship: A Systematic Review. J Med Internet Res. 2017;19(1): e9.

6. Balashov K. Hromadske zdorovia ta kultura: tochky dotyku. Modern science: problems and innovations. Abstracts of the 3rd International scientific and practical conference. Stockholm: SSPG Publish. 2020;7479. (In Ukrainian).

7. Hulchiy 0., Slabkiy G., Balashov K. Evidence-based approaches to communication of non-communicable diseases risks in Ukraine: identification of channel. Ukraine. Nation's Health. 2020(4);6-12.

8. United Nations Children's Fund, State Statistics Service of Ukraine, Ukrainian Institute for Social Reforms and Statinformconsulting. Ukraine Multiple Indicator Cluster Survey (MICS) 2012. Ref. UKR_2012_MICS_v01_M. https://microdata.worldbank.org/index.php/catalog/2348 on 30.11.2019.

9. Falcone R., Sapienza A. How COVID-19 Changed the Information Needs of Italian Citizens. Int J Environ Res Public Health. 2020;17(19):6988. doi: 10.3390/ijerph17196988.

10. Gerbing K.K., Thiel A. Handling of medical knowledge in sport: Athletes' medical opinions, information seeking behaviours and knowledge sources. Eur J Sport Sci. 2016;16(1):141-8. doi: 10.1080/17461391.2014.989278.

11. LecerofS.S., Stafström M., Emmelin M. et al. Findings from a prospective cohort study evaluating the effects of International Health Advisors' work on recently settled migrants' health. BMC Public Health. 2017;17(1):369. doi: 10.1186/s12889-017-4273-0.

12. Miteniece E., Pavlova M., Rechel B., Groot W. Barriers to accessing adequate maternal care in Central and Eastern European countries: A systematic literature review. Soc Sci Med. 2017;177:1-8. doi: 10.1016/j. socscimed.2017.01.049.

13. Jervelund S.S., Maltesen T., Wimmelmann C.L. et al. Know where to go: evidence from a controlled trial of a healthcare system information intervention among immigrants. BMC Public Health. 2018;18(1):863. doi: 10.1186/s12889-018-5741-x.

14. Vrdelja M., Kraigher A., Vercic D., Kropivnik S. The growing vaccine hesitancy: exploring the influence of the internet. Eur J Public Health. 2018;28(5):934-939. doi: 10.1093/eurpub/cky114.

15. Stahl J.P., Cohen R., Denis F. et al. The impact of the web and social networks on vaccination. New challenges and opportunities offered to fight against vaccine hesitancy. Med Mal Infect. 2016;46(3):117-22. doi: 10.1016/j.medmal.2016.02.002. 
16. Učakar V., Fafangel M., Kraigher A. Vaccine confidence among mothers of young children, Slovenia, 2016. Vaccine. 2018;36(37):5544-5550. doi: 10.1016/j.vaccine.2018.07.062.

The authors received no specific funding for this work. The studies were carried out as part of the research work "Scientific and methodological investigation for the development of human resources in the field of public health in Ukraine", State Registration Number: 0117U002464. Study period: 2017-2020.

\section{ORCID and contributionship:}

Kostyantyn V. Balashov: 0000-0002-7820-4527 A, C, D, E, F

Prof. Olesya P. Hulchiy: 0000-0001-8283-8672 A, E, F

Prof. Gennady O. Slabkiy: 0000-0003-2308-7869 A, E, F

Dr. Nadiia M. Zakharova: 0000-0002-6530-6217 A, E, F

Solomiya M. Turianytsia: 0000-0002-4294-198X A, E, F

\section{Conflict of interest:}

The Authors declare no conflict of interest.

\section{CORRESPONDING AUTHOR}

Kostyantyn V. Balashov

Shupyk National Healthcare University of Ukraine

9 Dorohozhytska str., Kyiv, Ukraine

tel: +380668994380

e-mail: kostyantyn.balashov@gmail.com

Received: 13.11 .2020

Accepted: 07.03.2021

A - Work concept and design, B - Data collection and analysis, C - Responsibility for statistical analysis,

D-Writing the article, $\mathbf{E}$-Critical review, $\mathbf{F}$ - Final approval of the article 